\title{
Traditionalism Nazhir Kyai on Waqf Asset Development in Bangkalan Madura
}

\author{
Muttaqin Choiri ${ }^{1}$, Ahmad Makhtum ${ }^{2}$ \\ ${ }^{1,2}$ Universitas Trunojoyo Madura
}

\begin{abstract}
This research aims to identify the model of waqf asset management by religious leaders (kyai) in Madura, which serves to support and optimize asset waqf utility nationally, which has not been well empowered. This study focuses on (1) knowing the management and development of waqf capital assets by Kyai as Nazhir in Bangkalan, and (2) to determine the analysis of the waqf asset development model in order to increase the benefit of waqf assets in Bangkalan.

A qualitative approach was used in the present study. Data retrieval techniques with documentation and in-depth interviews on the management of waqf assets in Bangkalan using component analysis on waqf core principles standards.

The results of the research showed that waqf assets managed by kyai were transferred to posterity without going through the changing nazhir process, which impacted on the unfulfilled aspects of waqf development, which is based on aspects of knowledge, training recruitment, rewards, and aspects of coaching and supervision.
\end{abstract}

Keywords: Waqf Asset; Kyai; Traditionalism.

*Corresponding author: muttaqin.choiri@trunojoyo.ac.id

Received: September 22, 2020; Accepted: January 09, 2021; Published: June 16, 2021

\footnotetext{
Abstrak: Penelitian ini bertujuan identifikasi model pengelolaan harta wakaf yang dikelola oleh tokoh agama (kyai) di Madura, yang berfungsi mendukung upaya dan optimalisasi pemanfaatan harta benda wakaf secara nasional yang selama ini terkesan belum diberdayakan dengan baik. Dengan fokus pada tujuan, (1) mengetahui pengelolaan dan pengembangan aset kapital wakaf oleh Kyai sebagai Nazhir di kabupaten Bangkalan, dan (2) untuk mengetahui analisis model pengembangan aset wakaf dalam rangka meningkatkan kemanfaatan harta wakaf di kabupaten Bangkalan.

Penelitian ini menggunakan pendekatan kualitatif. Teknik pengambilan data dengan dokumentasi, wawancara mendalam pada kyai pengelola harta benda wakaf di Kabupaten Bangkalan, dengan menggunakan analisas komponensial pada standar waqf core principles.

Hasil dari penelitain, menunjukkan aset wakaf yang dikelola oleh kyai banyak diturunkan baik ke anak сисu, tanpa melalui proses pergantian nazhir, yang berdampak pada tidak
} 
Muttaqin Choiri, Ahmad Makhtum, : Traditionalism Nazhir Kyai On Waqf $\mid 73$

terpenuhinya aspek pengembangan wakaf, yang didasarkan pada aspek pengetahuan, pelatihan, rekrutmen, imbalan, dan aspek pembinaan dan pengawasan.

Kata kunci: Aset Wakaf; Kyai, Tradisionalisme

\section{INTRODUCTION}

The development of waqf regulation in Indonesia has changed several times, most recently with the ratification of Law No. 41 of 2004 on Waqf and Government Regulation No. 42 of 2006, providing a new paradigm ideological and socioeconomic paradigm (Kementerian Agama RI, 2013, p. 45). First, the concept of waqf "investment" has a religious ideological basis so that the ummah looked up the wealth owned by a person with a humanistic value. Second, the socio-economic paradigm of waqf contributes positively to the economic problems of ummah.

In fiqh terms, the notion of waqf has many perspectives. Among the things expressed by Imam Shafi'i is the waqf is to release the assets that give from the ownership of wakif, after the perfect procedure of waqf, namely after the fulfillment of the conditions, pillars and pledges of waqf carried out, by "no longer doing control over the goods or assets, which turns into the possession of Allah, with the necessity to take the value of benefit for the social good. (Az-Zuhaili, 1985, p. 154), Meanwhile, the use of its value is carried out by maintaining the main capital of its waqf, (Bakr, p. 319), which means that waqf is one of the processes of how the principal of waqf assets survive, not reduced, but with a good management of waqf assets actually has an increase in value over time.

The term Waqf for our society is the transfer of ownership of assets that was originally a right of owner that wakif (who donates assets) to be handed over to the recipient of the waqf who will manage the assets of waqf. Ownership of wealth and turnover of assets by a group of people has the potential to cause social instability, exploitation of poverty by the rich, (Khosyi'ah, 2010, p. 12) that Islam taught the distribution of wealth is carried out through philanthropic pranata, including waqf, which contributes to social security and harmonization as a bridge between the rich and poor as an economic force for the Muslim community. (Saad, Azis, \& Sawandi, 2014, p. 508). Conceptually, waqf is used as a source of funding that contributes to the benefit of all time, (Nurul Huda, 2016, p. 2) with the regulation of waqf in various Muslim countries including Indonesia, it is expected that waqf management can play its role in such a way, in the management, utilization and also economic empowerment for the community

Law No. 41 of 2004, the waqf element is stated as follows: Wakif, Nazhir, Wakaf Assets, Wakaf Pledge, Wakaf Allocation, and Waqf Period. In addition to the fulfillment of these six elements in the administration of waqf, the purpose mandated by the Waqf Law in Articles 4 and 5 states the use of waqf assets in 
accordance with its function and in order to realize the potential and economic benefits used to promote general welfare..

The Indonesian government's spirit in maximizing the potential and usefulness of waqf in this rule was affirmed by the establishment of the Indonesian Waqf Agency, which serves as an independent institution; three years after the Waqf Law was passed through Presidential Decree No. 75/M of 2007, which serves as a nazhir builder to foster the management of waqf assets to be better and productive in order to produce greater benefits for social services, economic empowerment, or as a public infrastructure development. The original purpose of waqf, which was originally described by the Hadith of the Prophet as part of individual investments that will be eternal, with a perpetual flow of reward as long as the waqf wealth provides benefits as part of the benefits of shodaqoh jariyah, began to be used as part of worship that not only serves to keep hablun min Allah, but also has developed toward Hablun min an-naas, with the intention of getting both good at once.

The sign of waqf management in Indonesia has several aspects, including: (a) the obligation to record waqf pledges, (b) the expansion of waqf assets, which is not only limited to land and buildings; (c) the allocation of waqf assets is expanded not only in religious and social facilities but also in the expansion of economic benefits; (d) it is necessary to increase the ability of Nazhir (read: manager) waqf, and (e) it is necessary to form a national waqf institution. (Fahruroji, 2019, p. 2). Based on this regulation, waqf development data have increased significantly.

Nazhir Waqf is a party that receives waqf assets from wakif (who donates assets) to be managed and developed based on designation in the waqf pledged, which is discussed in Section 11 of the waqf law. It has the following tasks: (a) administering waqf assets, (b) managing and developing waqf assets according to its purpose, function, and designation; (c) supervising and protecting waqf assets; and (d) reporting the task implementation to the Indonesian Waqf Board. Compared to other philanthropic instruments in Islam, such as zakat, infaq, and shodaqoh, whose asset ownership status belongs to mustahiq zakat, consisting of eight groups of zakat deserves, in contrast to the waqf after the pledge of waqf that the assets waqf ownership status of wakif switch and under the control of Nazhir, which was given autority to manage, utilize, and emopower capital assets wakaf accordance pledge waqf from wakif for the benefits and benefits of the ummah. (DEKS Bank Indonesia - DES-FEB Unair, 2016, p. 45). Nazhir plays an important role in managing waqf assets, as mentioned in the waqf core principles, including the role of nazhir management, is a group or individual who is trusted by wakif to develop waqf assets, taking into account the ability of sharia and professionalism in the implementation and reporting of waqf asset management. (International Working Group on Waqf Core Principles, 2018, p. 10) 
Muttaqin Choiri, Ahmad Makhtum, : Traditionalism Nazhir Kyai On Waqf $\mid 75$ Asset Development In Bangkalan Madura

Nazhir is a part that receives waqf assets from people who have assets to be managed and developed according to its designation. (Direktorat Pemberdayaan Wakaf, 2006, p. 69), According to Hanafiyah nazhir wakaf called qayyim al-Waqf or mutawalli (Qal'aji, 1985, p. 404), which means managing and supervising waqf activities to maintain, protect, empower (invest), and collect profits to be distributed to recipients of the benefits of waqf property, as well as conduct activities related to the management of waqf assets.

Waqf assets are inanimate, although in the regulation mentioned waqf assets include moving and immobile objects, both types of assets will remain if left, but assets will be able to provide benefits if there is someone that optimizes the assets. The mandate of waqf regulation in Indonesia, as well as efforts to restore the role of waqf function as in the history of Islam, which serves as one of the sources of Islamic economic power in response to the most fundamental problems, including economic backwardness, lack of education, and lack of clothing and food.

Nadzir in Government Regulation 42 Year 2006, divided into 3 (three groups: Individually Nazhir, Organization Nazhir, and Nazhir Legal Entity. In its description, the three Nazhir groups must be registered with the Minister of Religious Affairs and the Indonesia Waqf Board through the Office of Religious Affairs, where Nazhir or wakaf assets are located.

Therefore, important and strategic functions of nazhir wakaf, as a group that is trusted to develop the wealth of waqf nazhir needs to have general requirements, as mentioned by Fathurrahman Djamil (Kasdi, 2014, p. 218), Nazhir are expected groups or people who are able to portray themselves as First General Leaders in akhlaq, have noble character, trust, good behavior, experience, mastery administrative and financial sciences that are considered necessary to carry out their duties in accordance with the type of waqf and its purpose. Second, Nazhir was able to work in accordance with the provisions of the waqf law in accordance with the decisions of the organization as well as the board of waqf management. In carrying out its daily duties, always maintaining the integrity of waqf property, increasing the purchasing of waqf assets, as well as distributed benefits; third, the subject is supervised by both the Ministry of Religious Affairs and the Indonesia Waqf Board, as well as reporting its activities at least once every three months; and fourth, Nazhirs are personally responsible for losses or debts arising and contrary to waqf law. These four qualification requirements need to be owned by Nazhir in order to maintain and develop waqf capital assets.

In addition to these four general requirements, the Directorate of Zakat and Waqf Development (Kementerian Agama RI, 2013, p. 82) provides parameters to realize the governance of good waqf development by nadzir, referring to Prophet Muhammad SAW, in a theoretical framework on the four traits that must be owned by Nazhir (a). Amanah (trustworthy), in managing waqf both input and output 
nazhir resources, which include aspects of education, skills, performance sharing, standards of rights and obligations, and clear operational standards; b) Shiddiq (honest), both on the personality of nazhir and the form of programs offered, this honest nature in order to maintain wakif and masarakat trust; and c) Fathanah, which means intelligence. This parameter is needed by nazhir in order to create a waqf management program that can be accepted by the community, such as by being able to open up economic improvements to the small communities around, whose benefits are able to realize the welfare of many people; d) Tabligh, (conveying correct information), which includes the willingness and ability to inform the good and correct, related to the report on the utilization of waqf assets, and readiness to be audited.

The fulfillment of general requirements based on the determination of the parameters arranged, in order to avoid the maximum management of capital assets wakaf so great potential in supporting the life and economic governance of the community around the property waqf, which has been caused by (Baharuddin $\&$ Iman, 2018, p. 70), by knowledge factor, which include knowledge of waqf provisions in both figh and law in Indonesia, as well as contemporary studies on the development and empowerment of waqf, coaching factor carried out both by government, involvement of religious universities and the like has not been done for active efforts involvement in the improvement of nazhir competence through coaching, recruitment factor, that are often based on "who is capable" and "who wants" and hereditary traditions nazhir wakaf, reward factor (ujrah) there is still no regulation for example about the standard of wage acceptance that can be obtained by nazhir, making nazhir not motivated to work better, competency factor, which the management of waqf assets is often not based on expertise, and more based on the trust and personal approach, supervisory factor that becomes the element of maintaining waqf assets, in order to be supervised and the nazhir does not release its responsibility.

Along with the regulation and development concept of management, utilization, and empowerment of waqf through waqf regulation in Indonesia, the capital of waqf assets is encouraged to be an optimal instrument of economic strength through the system and direct management in accordance with Islamic sharia, as well as the benefits of Indonesian waqf boards for developed professionalism nazhir. (Kementerian Agama RI, 2013, p. 104).

On the other hand, Madurese, in general, and especially in Bangkalan, the belief that kyai is the most worthy and representative figure to receive waqf. (Aji, Harisah, \& Mukri, 2020). Waqf data in 2019 recorded waqf land in Bangkalan, which has a waqf area of 86,05 ha, with a total of 949 land that spread across various villages and sub-districts in Bagkalan, and the value of the benefits of assets is sequentially used as mosques, schools/madrasahs, pesantrens, tombs, and other 
social purposes. (SIWAK , 2020), with nazhir managers as individuals, organizations, and legal entities. The traditional management of waqf among those that occurred limited both waqf assets and nazhir regarding the number of nazhir personnel and management skills of waqf assets owned by nazhir waqf(Zaenurrosyid, 2018, p. 60), while the regulatory mandate mentions that management of waqf profesionally by nazhir is an important instrument in the implementation of waqf regulation, among which nazhir is one of the pillars of the waqf law, which means it becomes valid for the modenization of waqf capital asset management through the management of the nazhir professional management system.

Madura society is famous for its distinctive, unique, stereotypical, and stigmatic culture, this peculiarity refers to the notion that the madurese ethnic entity has a different character to the community in other ethnicities, among the cultural peculiarities described through compliance symbolized by bhuppa' bhabhu ghuru rato (Wiyata, 2002, p. 1) which is interpreted in Indonesian means fathers, teachers / kyai, and queen or government. This symbolization illustrates how long this structure has lasted for a madurese society collectively produced and, at the same time, become a pranata of social life and become a force that plays a role in social life (structuring structure), and manifests into a power structured by the social world (structured structure) (Sidiq, 2003, p. 103), which is inherited from generation to generation, and becomes a habituation that contrasts, in its development, although by still putting forward the tradition, madurese people make modifications to certain concepts of compliance based on their needs in complying with these figures. (Hefni, 2007, p. 20)

Kyai, who is described by madurese as one of the figures and becomes a social elite who is also a religious elite, has also transformed into a political figure for Bangkalan people, who put kyai and his descendants (lora) into a political elite, in local politics after the reform era. Entrenching the role of kyai in the social and religious structure of Madurese society also occurs in the management of waqf, among others, in the management of waqf, wakif handed directly to kyai as the figure closest to God, in this case not kyai politics (Aji, Harisah, \& Mukri, 2020, p. 736).

Kyai, which in Madura is commonly called kyaeh, is often described as a figure who has the influence of leadership institutions, and becomes a place to ask for fatwas both in the social sector, especially religious, with his accuracy and awareness of giving advice, making people obey, ready to serve this figure, even though this attitude sometimes exceeds the limits of fairness. For traditional society, a charismatic figure is able to create homogeneity that manifests in collective consciousness, lifestyle equality, and the same beliefs (Johnson, 1986, p. 81), by ordaining kyai as the earthly and ukhrawi leader, which is interpreted as God's 
representative on earth. (Anderson, 1972, p. 19). This trust then leads to its submission. Kyai figure in Madura society in most of its people occupies settlements consisting of units that spread out remote and centralized, meaning that residential buildings in Madura usually consist of large grounds consisting of four or five families who have relative relationships, and form "small villages," and some of these "small villages" form villages, which are united by religious centers, langgar rajeh and mosques, which among others is the assets of waqf, and led by a kyai (Hefni, 2007, p. 19), traditionally, has not been utilized professionally in order to empower and alleviate poverty, due to the lack of professional managers (nazhir) (Fauzia, 2015, p. 198) yang bagi masyarakat Madura lebih banyak diserahkan kepada kyai. for madurese people were handed over to kyai. From the charismatic side kiai, economic development of the people will be easier to realize because the position of kyai is actually a dynamator who is expected to be a cultural broker and even become a power broker for the community of cultural communities. (Abidin, 2015, p. 168).

Other research results Zainal Abidin, "The Jihad Economic; The Spirit of Islamic Economic Movement By Kyai in Madura" focused on Pamekasan Madura district, concluded that kyai who have businesses and businesses are capable of dealing with all levels of hierarchy of needs, and can freely do idealism kyai without thinking too much about the intervention of other parties. (Abidin, 2015)

These two roles, as the guardian of religious traditionalists on waqf capital assets or business instincts to develop waqf capital assets, become an interesting study in the development and empowerment of waqf in Madura, and Bangkalan more specifically.

Third research by Abd. Syakur, dkk, "Waqf Governanca in Improving Comunity Welfare in Jember, " research focusing on waqf management in Jember that waqf management in Jember has been adjusted to the standards in the applicable regulatory guidelines, but still has not been implemented properly overall, caused, among others, the formation of BWI in Jember; the ego of the heir of waqif who wishes to regain control of the land and mismatch with the management; nazhir is still less professional in carrying out tasks and not as the main task (work), as well as low public understanding of the formulation in waqf regulation, due to the lack of socialization. (Abd. Syakur, 2018).

The three results of the study have not touched on kyai's efforts to develop capital assets of waqf assets; the first study shows that public confidence in kyai as a manager of waqf assets has not been based on the professionality of kyai, but the emotional closeness side of which is a blessing from ghuru. This research, which underlies the need to elaborate on the development carried out by kyai in utilizing waqf assets in Madura that generally and Bangkalan more specifically. 
Through the second research, along with the need for economic strength, selfreliance carried out by kyai, by doing certain business activities that will actually increase the dignity of kyai. The mention of business kyai in Madura suggests that kyai if gained knowledge and how to develop waqf assets will be able to manage waqf assets well, which will support or weaken the initial allegations in the research to be conducted, in order to map the development of waqf assets by kyai in Bangkalan.

The analysis of the implementation of waqf capital asset development by the kyai in Bangkalan is expected to be a direction and guidelines for the implementation of waqf capital asset utilization activities based on waqf development management patterns and become one of the potential economic, social, and political improvement of waqf beneficiaries, as well as being part of the wakaf asset management empowerment program. Design research on how to develop waqf capital assets by kyai as nazhir wakaf in Bangkalan district and waqf development model based on Waqf Core Principles in Bangkalan?

\section{RESEARCH METHODE}

Research on waqf development by Kyai in Bangkalan uses qualitative research methods to obtain descriptive data in the form of written words or from people's oral and observed behavior, as expressed by Moeloeng qualitative research, is used to understand how behavior, perception, motivation, and action of waqf development by nadzir kyai holistically, in a descriptive way in the form of words and language in the natural context.

Phenomenological approach options are used to describe the model of development of waqf capital assets by kyai in managing waqf by describing the meaning of activities and experiences that have been done by kyai about the concept or phenomenon of management and development of waqf capital assets in Bangkalan. Data collection in qualitative research is conducted by using techniques determined based on data taken from waqf data at authorized agencies as the primary data source, as well as more use of observation or observation participation, in-depth interviews, and documentation.

Research on the development of waqf capital assets by kyai in Bangkalan used to describe the development activities carried out by kyai as nazhir wakaf in Bangkalan, data analysis in this research using component analysis as developed by Spradley, this analysis to organize the development of waqf capital assets that have differences between each other include the objectives of waqf, the foundation of waqf development, management system and waqf development, as well as aspects of the security and benefit of waqf property carried out by kyai in Bangkalan, so that models can be obtained development of waqf capital assets by nadzir kyai in Bangkalan, in accordance with the standards formulated by the Indonesian Wakaf 
Board through Core Principles for Effective Waqf (International Working Group on Waqf Core Principles, 2018).

\section{RESULTS AND DISCUSSION}

Kyai, who became the central and religious belief in Bangkalan specifically and the madura region, is a figure in religious practice for the people in the region, which is the basis for most people in Madura who allocate and give some part of his wealth in the form of land (immovale assets of waqf) entrusted its utilization by kyai, with various uses ranging from mosques, mosques, madrasahs, boarding schools, and a small part of social utilization. (Sulaiman, 2020).

Kyai in Bangkalan community, as affirmed by the head of the KUA Socah subdistrict as a role model, which is not only about religious issues, but also about mu'amalah activities (trading, working) that often still ask kyai for certain instructions when someone wants to do or start a job, related to a soul mate or married couple, and late kyai also plays a role in political struggles at both the executive and legislative levels.

Nazhir Kyai data, based on SIWAK data on Religious Sealing as follows:

tables 1 : The number of Nazhir Kyai in Bangkalan

\begin{tabular}{|c|c|c|}
\hline Sub District & Nazhir Kyai & Mauquf Bih \\
\hline Bangkalan & 1 & 55 \\
\hline Kamal & 2 & 29 \\
\hline Socah & 2 & 42 \\
\hline Burneh & 4 & 75 \\
\hline Arosbaya & 2 & 33 \\
\hline Geger & 3 & 77 \\
\hline Klampis & 2 & 41 \\
\hline Sepulu & 0 & 50 \\
\hline Tanjung Bumi & 2 & 94 \\
\hline Kokop & 7 & 73 \\
\hline Kwanyar & 5 & 37 \\
\hline Tragah & 1 & 31 \\
\hline Labang & 1 & 22 \\
\hline Tanah Merah & 1 & 38 \\
\hline Blega & 4 & 46 \\
\hline Modung & 6 & 95 \\
\hline Galis & 1 & 82 \\
\hline Konang & 3 & 54 \\
\hline
\end{tabular}


The data only focus on the mention of nazhir kyai on SIWAK. This does not close the possibility of the name nazhir that does not list kyai as a degree of diversity for the community nazhir status as kyai.

As stated by the heirs of the wakif (who donated), the selection of kyai as nazhir wakaf is due to the principle of high trust, as well as the view of most people, Kyai in managing waqf property can be much more trusted to maintain waqf assets.

The existence of nazhir Kyai in Bangkalan carrying out the mandate of waqf that has been implemented for many years, in the position of nazhir has come down to posterity as the manager of waqf without going through the process of changing nazhir, as conveyed by KH. Muhammad Yahya, the waqf manager of Nurul Hidayah Parseh Socah Bangkalan Mosque, continued the management of the waqf mosque previously managed by KH. Nuruddin, while his current status has not been officially registered as a replacement nazhir. As conveyed by KH. Muhammad Yahya;

"Nurul Hidayah Mosque has not been certified because of the constraints of the previous people are still lay about the legality of waqf and some parties also have concerns related to the waqf of the Mosque."

The efforts to continue the management of waqf by Nazhir, automatically to the family, also occurred in the waqf assets in the village of East Bilaporah Socah. Kh. Muta'al Amin succeeded his father, KH. Amin Sofyan as nazhir Majid Ar-Roisy, waqf process.

"The origin of this mosque is donated because there is no mosque, on the initiative of grandfather K.H sofyan built a mosque that was eventually converted to KH. Amin Sofyan as nazhir, with waqf status in the form of mosques and land, does not include the land around the mosque. At that time, the mosque and waqf land had been certified by nadzir village, but now the letter is gone."

Different things are conveyed by the son of late KH. Ishaq Khatib, formerly Nadzir, was used as an educational institution in the village of West Sukolilo. Nazhir's descendants only learned that the assets he managed for the development of educational institutions were waqf land managed by his father, after Nazhir was registered with KH. Ishaq Khatib has passed away.

"Some waqf deed letters, I only got after Abah died. Currently, I have not taken care of the nazhir replacement. Among the obstacles, the waqf asset certification process was previously assisted by the implementation of honorary extension workers who are currently out of office, so that wakif searches are also not easily detected properly."

Official of The Office of Religious Affairs of the Labang sub-district, he said:

"Along with the change of head of Office Religious Affairs, employees and some workers of data about waqf, some data are no longer available in the office. 
Information about waqf data that has been long and our archives can no longer track it, including about wakif information even nazhir wakaf."

Management of waqf assets by Kyai as recorded in SIWAK information and searches for waqf locations, among others, signaled a change in the status of waqf land, one of the descendants of Nazhir Kyai in Kamal District said:

" The status of this educational institution, formerly a building al-Muawanah boarding school, is currently used as a kindergarten school Al-Mursyidiyah, with the status of land ownership is private property since 2006."

The development of Waqf assets in Bangkalan from a total area of approximately 90 ha, managed by Nadzir Kyai (14.3 ha), as shown in Table.

Tables 2 :land area total Wakaf based on its designation in Bangkalan

\begin{tabular}{lcc}
\hline \multicolumn{1}{c}{ Utility } & Total & Land area $\left(\mathbf{M}^{2}\right)$ \\
\hline Mosque & 64 & 61.872 \\
Boarding School & 11 & 14.212 \\
Prayer Room (Musholla) & 7 & 1.632 \\
School & 25 & 54.071 \\
Other Social & 4 & 10.081 \\
Tomb & 1 & 526 \\
\hline
\end{tabular}

In utilizing waqf assets, Nazhir's professionalism relates to how nazhir's ability to work in accordance with the provisions of waqf laws and supporting regulations. Related to the duties of nazhir's function, such as maintaining the integrity of waqf assets, increasing the price power of waqf, and distributing the benefits of waqf assets.

" To maintain the integrity of waqf assets, Nazhir Kyai conducts renovation, expansion, and improvement activities. The law on waqf is good; it is necessary to manage waqf affairs (read: Ministry of Religious Affairs, Indonesian Waqf Board) in carrying out socialization or training, managing the old waqf assets are given assistance, or how easy it is to take care of the certification of waqfnya. " (Yahya, 2020)

Meanwhile, Kyai Jazuli, as Nazhir of Nurul Amanah Islamic Boarding School said that:

"with waqf managed well by Nazhir Kyai, such as the development of this pesantren, can minimize the existence of conflict. Therefore, Kyai Jazuli chose his family land, his wife, and children as waqf assets by appointing himself as a nazhir wakaf. By being used as waqf assets, land assets are no longer inherited or granted, even contested. In addition, the reward is greater and can minimize the conflict. Until now, Nurul Amanah developed in the education sector consisting of formal and non-formal institutions, but also began to target business activities, including through cooperation with the Indonesian Bank, such as E-NURA to accommodate 
electronic transactions santri, as an effort to safeguard and develop waqf assets." (Jazuli, 2020)

In addition to being based on the waqf pledge, it is also based on the applicable rules and regulations, including Law No. 41 of 2004 on Waqf.

" Currently, I manage the waqf of this mosque is also still not legal, there is no official nadzhir replacement process, which is the authority of the Indonesian Waqf Boards, so it is still difficult for us to do the certification process of this waqf land" (Yahya, 2020)

According to the Head of Shariah Implementation Section of the Ministry of Religious Affairs Bangkalan

The Waqf Pledge process carried out by both nazhir and wakif is often limited only to the completion of the Waqf Pledge Deed, which does not proceed to the next process, such as certification of waqf land. Formality efforts to implement the deed of waqf pledge in the Office of Religious Affairs, related to waqf recipients' interests, such as madrasahs and foundations, to be able to access infrastructure assistance from the government, related to the status of waqf land'. (H. Sulaiman, 2020)

In maintaining the integrity of waqf assets by Nazhir Kyai, according to some narration, mentions:

" The mosque building on this waqf land has been renovated as much as three times this time, in addition to the expansion of the building for painting, the addition of existing facilities in the mosque, considering the more days the mosque worshippers. The mosque renovation fund is taken from infaq, alms from the surrounding congregation, and other donors, who do not reduce waqf assets, including myself, do not get rewarded as the manager of waqf land, because the waqf in the form of this mosque is part of the fight for the religion of Allah." (Yahya, 2020)

"In addition to developing the physical buildings that stand on waqf land, the manager also further improves the quality of the institution's benefits. Equipping students with a variety of knowledge as well as skills, academic and non-academic achievements, increasing the attractiveness of santri this boarding school, along with the development, waqf land will continue to have benefits that can be felt by various parties'. (Jazuli, 2020)

"I am the granddaughter of kyai Sabar., as my previous kindergarten building is a pesantren land managed by my grandfather, since 2006 this kindergarten was only established, which is officially a family private land, not recorded as waqf land." (Rofiqoh, 2020)

Waqf assets according to waqf law is a property that must always be protected, in the Waqf Law, it is stated "nazhir Wakaf, has an obligation to administer properly, and submit and comply with waqf regulations, as an effort of the government to 
maintain waqf assets. Among others, nazhir routinely reports the utilization of waqf assets to the Indonesian Waqf Boards or the local Ministry of Religious Affairs. "I have never communicated about the issue of changing nazhir with the authorities, until now also never received information, training or socialization directly from the Ministry of Religious Affairs on how to manage good waqf assets, including about routine reports and so on."(Ishaq, 2020)

"So far, we have never received explanations and obligations nazhir about the necessity to report the utilization of waqf assets, in practice we still try to maintain the integrity of waqf assets by establishing religious facilities, as mandated by wakif, although initially the land used as waqf here was also originally private land, which was converted for the mosque." (Amin, 2020).

"So far, the waqf pledge process that occurred is limited to fulfilling the legal aspects of the waqf pledge process. After the waqf pledge process, many nazhirs no longer continue the process of land certification in the National Land Agency, in addition to the cost factors that need to be spent pad a process of land certification, and the certification of waqf land is not an administrative requirement of the application of social assistance required by the institutions'. (H. Sulaiman, 2020)

In every Office of Religious Affairs, has non-civil servant religious counseling, which among others served in the counseling waqf, as the existing reports so far, the counseling process is carried out on several occasions.". (M. Zakariya, 2020)

\section{DISCUSSION}

Based on the exposure of the data as stated above, aspects of the development of waqf capital assets in Bangkalan district to meet waqf development standards can be shown as follows:

First, the knowledge factor, in terms of knowledge possessed by Nazhir Kyai in the issue of waqf fiqh, nazhir itself is able to mention the values of waqf immortality that need to be maintained and provide benefits for people who are donated. Kyai, for both the Japanese and Madura people, is an Islamic leader for the surrounding community and is seen as able to become Ulama' in Islam, either a kyai leader of boarding school or Kyai who does not have a boarding school. As conveyed by Sartono Kartodirjo, kyai is an important figure that can shape the social, cultural, and religious life of the surrounding community. (Katodirjo, 1970, p. 114). Kyai, who is used as a spiritual and social leader figure, is also always portrayed as a person who has the power in various aspects, the ability to be a leader, directing general affairs, as a place to gain enlightenment, such as the affairs of soul mates, garden-matched rizki, career, and politics, no exception to religious issues in Waqf. As for the knowledge of the immortality of waqf as a flowing jariyah charity, and the foundation of waqaf fiqh, nazhir Kyai is able to decipher well, but in terms of waqf regulation in Indonesia, such as laws and other regulations, including the 
obligation to report changes in nazhir, the replacement of waqf assets is still a problem for nazhir kyai and his descendants as waqf asset managers.

Second, the empowerment factor in order to maximize the potential of waqf property requires a massive movement, based on the Regulation of the Indonesian Waqf Boards No. 22 of 2012 concerning representatives of the Indonesian Waqf Boards in the Regency/City and Province, that is, Nazhir empowerment in managing and developing waqf assets. The construction of the nazhir waqf has never been obtained for Nazhir. The non-running aspects of empowerment in the process of waqf development, more to the scale of priorities that become the passion of the development institution. Indonesian waqf boards on the scale of districts and provinces still have limitations in funding and no ownership of assets that can be developed; however, the Ministry of Religious Affairs has a number of basic tasks and large functions, such as marriage, hajj, education, madrasah pesantrens, universities, and even halal products, including waqf, which is still not a priority scale. In the Waqf Law, it is expressly conveyed that empowering is a BWI area, but because BWI is institutionally weak, not upstream to downstream policyholders waqf land, for example, its role is still considered weak. (Razak, 2020) For example, the Ministry of Religious Affairs was the first institution to issue a certificate of waqf pledge through (PPAIW in KUA), then the nazhir database is located in KUA, which means that the Indonesian Waqf Boards do not have clear and structured empowering data.

Third, the recruitment factor in the management and development of waqf assets in Bangkalan, there is no good recruitment process in the management aspect (nazhir). Nazhir is entrusted to those closest to them, both geographically and familially. For example, a wife as a wakif, a nazhir entrusted her husband, or a father who made his land with his son. This is a practice that is allowed in Fiqh because a wakif is given full authority to appoint the nazhir he wants; in the event that it does not appoint directly, then the authority is given qadli from the part where the place of asset waqf, (Azis, 2000, p. 89) which is different from the concept adopted in the Waqf regulation, which prioritizes the appointment of nazhir as one of the elements of waqf validity. The practice that occurs in nazhir Kyai as a religious figure in a village, partly because kyai has a good proximity to the geographical and psychological side and a reference for wakif, who is indirectly given the authority to be nazhir by Wakif, to take care of the administrative process and its processing through the pledge process at the Office of Religious Affairs.

Fourth, the reward factor was. Rewards are economically reciprocal, obtained from efforts made by nazhir in the framework of the development of waqf assets, as explained below:

لاجناح على من وليها أن يأكل منها بالمعروف .Al-Asqolani, 2000, p. 502) 
This statement is also affirmed in Article 12 of the Waqf Law that nazhir can receive compensation from the net proceeds for the management and development of waqf assets that do not exceed $10 \%$ (ten percent). Allowed to take this reward still not a culture in nazhir kyai in Bangkalan, because waqf for nazhir is a field of worship, and not to find a place to live someone's life. This expression is in line with the main purpose of waqf, namely for the common good, and has not attempted to provide a viable economic sustainability effect for waqf managers.

Waqf, which serves as an instrument of economic mobilization and development, will be a special attraction for nazhir if its economic needs can also be met properly from the management of waqf assets. For example, Hashim Kamali mentions the rethinking of human needs, which, according to Al-Ghazali, through the concepts of dharuri, hajiyat, and tahsiniyat, placed the order with a basic level of hifdzuddin (preservation of religion), hifdz an-Nass (preservation of the soul), hifdz al-maal (preservation of property), hifdz al-Aql (preservation of reason), and hifdz an-Nasl (preservation of descendants), (Auda, 2015, p. 34) which is the essence of human life, but according to Hashim Kamali, the preservation of the soul should be the first and foremost order, making the soul (life) awake, can be followed by other top guards, including religion. (Lena Larsen, 2009, p. 26) For Hashim Kamali, the soul plays an important role in raising awareness of the reason for the principle and spiritual values, which keeps wealth and descendants awake. Similar to Maslow's thinking, which prioritizes physical needs (physiological needs) as the most basic needs for humans, which include biological needs, air, food, water, and so on (Goble, 1971, p. 28); in this case, the fulfillment of physiological needs such as rewards for nazhir has a close relationship with the development of waqf, because concentration in developing, empowering waqf assets if not comparable to the fulfillment of physiological needs, then management becomes the last option, after the fulfillment of the needs of each nazhir. In this case, Nazhir Kyai in Bangkalan did not directly benefit economically, either in the form of salaries, benefits, or facilities obtained. The profits gained are more toward social gains. Among other things, it can get more affordable access to educational and religious facilities.

Fifth, competency factors, in terms of the development of waqf assets nazhir competence in line with the professionalism nazhir in running and functioning waqf to the maximum, as well as providing benefits to the target waqf. The management of nazhir Kyai in the functioning of waqf assets is limited to its use as a place of worship and educational institutions targeted at the waqf pledge. Efforts to develop waqf assets that function economically and benefit the ummah have not been running. For example, the development of mosques, which are waqf assets, in order to maintain and maintain their sustainability, is done by seeking financial support from the community, which is different from the management of waqf that can be done professionally with the competence of waqf development such as Pondok 
Modern Gontor through the Waqf Agency Foundation, from the waqf land it owns, in addition to being able to maintain the existence of boarding schools, are also able to preserve waqf land, without waiting or applying for waqf land development funds to the community. (Kementerian Agama RI, 2013, p. 67). Competencies owned by kyai, which have a sense of bussiness such as in Nurul Amanah Bangkalan, for example, began to initiate waqf assets more productive, such as for pesantren cooperatives or other businesses, in contrast to waqf assets intended for mosque buildings that still do not have economic benefits for the general public. Kyai's business development competency was divided into three models: First, Kyai business, in this case, described Kyai, who is able to open and run a business with his own capital, with profits returned to Kyai. Second, business boarding is a Kyai business venture run with capital from waqf pesantren, which was developed with a profit model returned for the benefit of pesantren. Third, Kyai and Bussines boarding, in this case between Kyai and pesantren, run the business's wheel, which is equally berjaalan, with the provisions of Kyai's return to Kyai, while the profits obtained pesantren returned for the management of pesantren, with Kyai as a leader in the management of businesses and businesses run. (Abidin, 2015, p. 172)

Sixth, supervision is a process of observation conducted systematically to provide assurance that the implementation of activities or tasks of the organization goes according to plan, in accordance with the laws and regulations, also based on the principle of effectiveness and efficiency. In waqf governance, the accountability of waqf asset management has had mechanisms in accordance with regulations. In Government Regulation No. 42 of 2006, paragraph (1) supervision of waqf is carried out by the government and the public, both active and passive; (2) active supervision is carried out by conducting a direct examination of nazhir on waqf management, at least once a year; and (3) passive supervision is carried out by conducting observations on various reports submitted by nazhir related to waqf management.

In practice, the effectiveness and efficiency of the surveillance system on waqf assets managed by nazhir kyai does not run optimally, either from passive or active supervision. The continuity of the waqf database on the waqf data information page in the field, the turnover of the deceased nadzir, and even the change of waqf land without the approval of the authorized institutions showed that the surveillance practices did not go well.

\section{CONCLUSSION}

The results of this study showed that the data nazhir Wakaf Kyai, as in SIWAK, changed to the second and third generations, and did not update the data by the Ministry of Religion as the authorized institution of waqf database holder. The nonrunning process of the development of waqf capital assets in accordance with the mandate of the prevailing laws and regulations, partly because the status of Nazhir 
surrogates is traditionally passed on to children or grandchildren without going through the official change process, which triggers nazhir surrogates to be passive. Including the standard process of waqf development by Kyai, from the elements of Knowledge, Coaching, Recruitment, Rewards, Competencies, and Supervision did not go well, so the large assets of waqf managed by Kyai approximately 14 ha, have not been able to support the economic goodness of ummat. 


\section{REFERENCES}

Abd. Syakur, H. Y. (2018, Juni). Tata Kelola Wakaf dalam Meningkatkan Kesejahteraan Masyarakat di Kabupaten Jember. Al-Ihkam, XIII(1), 73-96.

Abidin, Z. (2015). The Jihad Economic : The Spirit of Islamic Economic Movement by Kyai in Madura. Share, IV(2), 166-186.

Aji, A. M., Harisah, \& Mukri, S. G. (2020). Positions of Kyai in Traditions and Ideologies of Traditional Waqf in Maduranese Communities. International Journal of Advanced Science and Technology, 29(7), 730-737.

Al-Asqolani, A. I. (2000). Fath al-Bari Sharhi Shahih Buhari (2 ed., Vol. V). Beirut: Daar Al-Kutuub Al-Ilmiah.

Amin, K. M. (2020, Agustus 04). Putra Nadzir KH. Amin Sofyan. (F. Y. Merinda Cahya, Pewawancara)

Anderson, B. (1972). The Idea of Power in Javanese Culture. Dalam C. Holt, Culture and Politics in Indonesia (hal. 19). Ithaca: Cornell University Press.

Auda, J. (2015). Membumikan Hukum Islam melalui Maqashid Syari'ah. Bandung: PT Mizan Pustaka.

Azis, Z. b. (2000). Fathul Mu'in Bisyarhi Qurrotu 'Ain. Semarang: Toha Putra. Az-Zuhaili, W. (1985). Al-Fiqh al-Islam Wa Adillatuhu (Vol. 8). Beirut: Dar alFikr.

Baharuddin, A. Z., \& Iman, R. Q. (2018, Desember). Nazir Wakaf Profesional, Standarisasi dan Problematikanya. Li Falah Jurnal Studi Ekonomi dan Bisnis Islam, 3(2), 62-74.

Bakr, T. A. (t.thn.). Kifayah Al-Akhyaar. Mesir: Daral-Kitab al-'Arabiy.

DEKS Bank Indonesia - DES-FEB Unair. (2016, Agustus). Wakaf: Pengaturan dan Tata Kelola yang Efektif. Jakarta: Departemen Ekonomi dan Keuangan Syariah - Bank Indonesia.

Direktorat Pemberdayaan Wakaf. (2006). Fiqih Wakaf. Jakarta: Direktorat Pemberdayaan Wakaf Kementerian Agama RI.

Fahruroji. (2019). Wakaf Kontemporer. Jakarta: Badan Wakaf Indonesia.

Fauzia, I. Y. (2015). Membangun Ekonomi Pedesaan dengan Financial Inclusioan Melalui Lembaga Keuangan Syariah. Jurnal Al-Nisbah, 1(2), 182-198.

Goble, F. G. (1971). Madzhab Ketiga Psikologi Humanistik. (A. Supratinya, Penerj.) Yogyakarta: PT. Kanisius.

H. Sulaiman, S. (2020, Agustus 22). Kasi Penyelenggara Syari'ah Kemenag Bangkalan. (A. M. Muttaqin Choiri, Pewawancara)

Hefni, M. (2007). Bhuppa'-Bhabhu', Ghuru, Rato; Studi KontstruktivismeStrukturalis tentang Hierarki Kepatuhan dalam Budaya Masyarakat Madura. Karsa, XI(1), 12-20.

International Working Group on Waqf Core Principles. (2018). Core Principles for Effective Waqf Operation and Supervision. Jakarta: Islamic Economis and Finance Department - Bank Indonesia.

Ishaq, K. A. (2020, Agustus 08). Putra Nadzir KH. Ishaq Dimyathi, Sukolilo Labang. (F. Y. Merinda Cahya, Pewawancara) 
Jazuli, K. (2020, Agustus 13). Nadzir Wakaf PP. Nurul Amanah Tanah Merah. (F. Yaumil, Pewawancara)

Johnson, D. P. (1986). Teori-teori Sosiologi Klasik dan Modern. Jakarta: Gramedia.

Kasdi, A. (2014). Peran Nadzir dalam Pengembangan Wakaf. Jurnal Zakat dan Wakaf, 213-226.

Katodirjo, S. (1970). Religious Movement of Java in the 19th and 20th Centurie . Yogyakarta: Gajah Mada University.

Kementerian Agama RI. (2013). Paradigma Baru Wakaf di Indonesia. Jakarta: Direktorat Pemberdayaan Wakaf Kementerian Agama RI.

Kementerian Agama RI. (2013). Pedoman Pengelolaan dan Perkembangan Wakaf. Jakarta: Kementerian Agama RI.

Khosyi'ah, S. (2010). Wakaf dan Hibah. Bandung: Pustaka Setia.

Lena Larsen, C. M. (2009). New Directions in Islamic Thought, Exploring Reform and Muslim Tradition. London: I.B Tauris.

M. Zakariya, M. (2020, September 20). Ketua Kelompok Kerja Penyuluh Fungsional Kemenag Bangkalan. (M. Choiri, Pewawancara)

Nurul Huda, N. R. (2016). Manajemen Pengelolaan Wakaf di Indonesia Timur. Ekuitas, 20(1), 1-16.

Qal'aji, M. R. (1985). Mu'jam al-Lughah al-Fuqaha'. Beirut: Dar al-Nafa'is.

Razak, J. A. (2020, September 23). Ketua Badan Wakaf Indonesia Propinsi Jawa Timur. (M. Choiri, Pewawancara)

Rofiqoh, J. (2020, Agustus 06). Cucu dari Nadzir KH. Sabar Banyuajuh Kamal . (F. Y. Merinda Cahya, Pewawancara)

Saad, R. A., Azis, N. M., \& Sawandi, N. (2014). Islamic Accountability Framework in the zakat funds management. International Conference on Accounting Studies (hal. 508-515). Kuala Lumpur: Elsevier.

Sidiq, M. (2003). Kekerabatan dan Kekeluargaan Masyarakat Madura. Dalam Soegianto, Kepercayaan, Magi, dan Tradisi dalam Masyarakat Madura. Jember: Tapal Kuda.

SIWAK . (2020, Mei 17). Diambil kembali dari Sistem Informasi Wakaf: http://siwak.kemenag.go.id/tanah_wakaf_kab.php?_pid=MC9jYk9XaE8r VERXNG1KRFFMckkyUT09\&_kid=TUQ1WHJQWE9oeTNsL2haSzhS Q3NCUT09

Sulaiman, M. (2020, Juli 21). Kasi Penyelenggaraan Syari'ah . (M. Choiri, Pewawancara)

Wiyata, A. L. (2002). Carok : Konflik Kekerasan dan Harga Diri Orang Madura. Yogyakarta: Lkis.

Yahya, K. M. (2020, Agustus 04). Nadzir Wakaf Masjid Masjid Nurul Hidayah Parseh Socah. (M. Cahya, Pewawancara)

Zaenurrosyid. (2018). Nazhir Profesional dan Pengembangan Kapital Aset Wakaf. Dalam J. M. Asmani, Zaenurrosyid, M. M. Ali, \& Sayogo, Wakaf Kunci Kemajuan Umat. Sleman: Aswaja Pressindo. 